
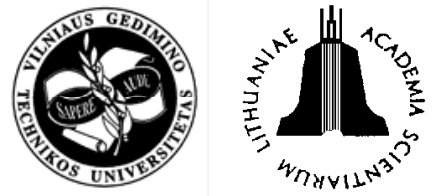

\title{
APPLICATION OF THE NON-LINEAR FE MODELS TO ESTIMATE EFFECT OF SOFT DEFECTS ON THIN WALLS OF STEEL CYLINDRICAL TANKS
}

\author{
Konstantin Rasiulis ${ }^{1}$, Michail Samofalov ${ }^{2}$, Antanas Šapalas ${ }^{3}$ \\ Vilnius Gediminas Technical University, Sauletekio al. 11, LT-10223 Vilnius, Lithuania. \\ E-mail: ${ }^{1}$ rasiulis@st.vtu.lt; ${ }^{2} m s @ f m . v t u . l t ;{ }^{3}$ antanas.sapalas@st.vtu.lt
}

Received 05 Oct 2005; accepted 21 Dec 2005

\begin{abstract}
Steel storage tanks and other structures of such kind of buildings have been extensively designed following the requirements of continuous cyclic operations. Because of many economically based reasons any engineering inspections of a huge volume are very expensive, so numerical investigations of the local defects are practically important. Natural inspection of tank dents (volumes of tanks were from 1000 to $50000 \mathrm{~m}^{3}$, diameter of dents from 0,40 to $4,50 \mathrm{~m}$, a depth up to $120 \mathrm{~mm}$ ) has shown that analytical approach of their investigation by using existing design standards is rather complicated. The main objectives of the presented investigations are: to determine an appropriate size of the finite element for geometrical defect modelling on thin wall of the steel cylindrical tank; to identify stress/strain state by using finite element method in the place of the defect; to define the appropriate results of the proposed analytical solutions and requirements of the codes with FEM results. The results, derived from the proposed formulas, are compared to those of natural inspection of real tanks and also with the results obtained by numerical modelling using the finite element method.
\end{abstract}

Keywords: steel cylindrical tank, defect, numerical modelling, finite element, geometrical non-linearity, physical non-linearity, stress/strain state.

\section{Introduction}

Rapid development in the world of huge industrial complexes in 1960-1970 became possible due to exact and effective analytical methods of calculations and analysis. It corresponded to the growth rate of the amount of products. Therefore the problems of residual resources of the engineering buildings, their defects, taking into account the operation features have not been considered as the questions of primary importance [1-5].

At present, considering the accumulated experience in using huge tanks, a deep knowledge of mechanically composed engineering systems and their behaviour as well as data concerning various factors important in an emergency situation have been collected [2-7].

Major repair or regular inspection of the large capacity thin-walled tankages is very expensive. Steel cylindrical tanks are an individual case of the thinwalled tankages. The common calculation of the tanks is not difficult for analytical and numerical methods. Strengthening of the places, where a perfect calculated form is disturbed, that is, at the spots of incuts, hatches, defects etc is a responsible part of the design of such constructions. The problems of prevention of defects during the operation period and repairs, as well as possibility to assure quickly the safety of defective places of the constructions are more important than the common calculations.
In the classical theory of defects [8-10] estimation of the problem has been presented for the „harp“ (incuts, cracks etc) and „,soft“ (dents, bulges, flaps etc) defects. The ,sharp“ defects are more dangerous because of a higher risk of the destruction. The ,soft" defects are not investigated so widely as the "sharp" ones and their limitation concerns the geometrical parameters only [11-17]. Moreover, the influence of such defects location, their forms, thickness of the wall tank etc has not been taken into account. The above-mentioned reasons show that the „soft“ defects are not sufficiently investigated and there is a possibility to improve their evaluation methods. Requirements of the international codes are considered below in details.

Table 1. Allowable imperfections depend on design Code

\begin{tabular}{l|l|l}
\hline \multicolumn{2}{c|}{ Standard } & Allowance \\
\hline \multirow{2}{*}{$\begin{array}{l}\text { ENV 1993-1-6: } \\
\text { Eurocode 3 }\end{array}$} & $\mathrm{A}$ & $f \leq 0,6 \%$ \\
\cline { 2 - 3 } & $\mathrm{B}$ & $f \leq 1,0 \%$ \\
\cline { 2 - 3 } & $\mathrm{C}$ & $f \leq 1,6 \%$ \\
\hline API 650 & $f \leq 1,4 \%$ \\
\hline SNIP III-18-75 & $f \leq 1,0 \%$ \\
\hline DIN 18800 & $f \leq 1,0 \%$ \\
\hline
\end{tabular}

Codes of designing and operating tanks exist in the USA, Russia and Germany (Table 1). This parameter $f$ is a depth of the dent. It cannot exceed a 
definite percentage of the dent diameter. The codes of the above-mentioned countries limit the dimension of the ,soft' defects during mounting and operation procedures [11-17]. According to the presented allowable deviations (Table 1) the codes differently limit the sizes of ,soft“" defects. In the Eurocode [12] the maximum deviation from a perfect form of the structure was proposed. It amounts to $1,6 \%$ of the dent diameter. In this case the structure is considered to be of a good quality, class ,C““. Accordingly, with smaller defect sizes the structure can be classified as the structure of a very good quality, class ,B“, or as the excellent quality structure, class „A“. The corresponding class of the structure is taken into account when analysing the stability of the shell by safety coefficient for each individual structure. In codes API, DIN and SNIP, the average values of deviations of the defects are used. These allowances are not used in calculations. The considered allowances are very common and do not take into account the place of defects, thickness of the shell, radius etc.

The manufacture and assembling of the cylindrical tanks with a capacity of 5000-50 $000 \mathrm{~m}^{3}$ are very complicated processes and thus already during putting them into operation the local defects are seen on the walls of the structures. The accumulation of the ,soft" defects and the increase of the available ones requires a regular evaluation of the tank fitness for further use. This question is very important for structures with a finishing operation period. A professional conclusion about the mechanical condition of the structure is of prime importance. Alongside with the plans of the company development the following conclusions can be made: a) expensive overhaul and further operation; b) examination of the tank replacement possibility.

On the other hand, actually a lot of tanks with the defect values exceeding those allowable by the codes $[6,7]$ are practically used, and this fact, as it follows from the observations, does not cause deterioration of the tanks state $[6,7]$. For the investigation of each specific case or a group of such problems, a series of simplifying assumptions are introduced taking into consideration the physical sense and the peculiarities of a specific situation [18-22].

However, the developments of accurate analytical models are particularly essential for the state investigation of the structures to be applied. To date such solutions are of special concern for practising engineers.

\section{Analytical models}

As a rule, the ,,soft' defects cause an increase of the stresses and deformations at the places with „sharp“ defects. According to the statistical data the lower strips of the cylindrical tanks are considered as a dangerous area. Undoubtedly it is connected directly with a border effect at the joint site of the tank wall and bottom. As follows from the above-mentioned data, many specialists in their investigations consider a wall having a defect which is supported onto bottom sheet and foundation.

Detection of the more accurate dependences between allowable values factors and parameters of the specific tank in the analysed investigations [7, 14, $21]$ is based on the analytical relations of the stress distributions, as well as on results of the observations of the defects on the tanks used. The methods of the defect evaluation on the pipes [23-25], as well as calculations of the stress concentration factors on the tensile plates [24] were widely applied for getting formula for calculating stress concentration factors.

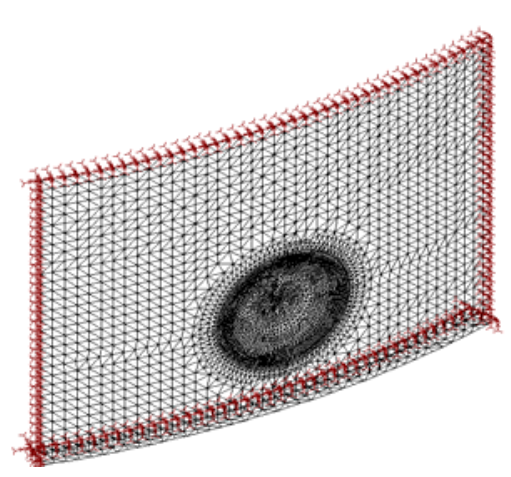

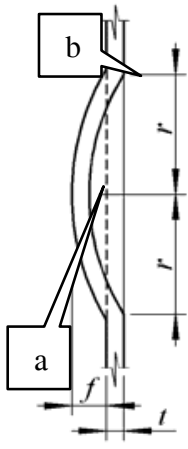

Fig 1. Numerical model (a); shape of the simulated semi-sphere defect (b)

The most dangerous points for the dent are upper points ,, (Fig 1). The most dangerous stress concentration factor with ,variable success“ is available in the areas mentioned. One more important feature when determining the stress concentration factor is appearance of its largest value in the region between points ,a“ and ,b“. The rest points of the dent are less loaded or unloaded in comparison with stresses on the wall of the tank without a defect.

The basic geometrical parameters of the defect can be relative radius values

$$
\beta(r, R, t)=\frac{r}{\sqrt{R t}}
$$

and relative depth

$$
\gamma(f, t)=\frac{f}{t} .
$$

The proposed formulas for the analysis of the wall stress condition across the dent area are expressed by a polynomial with empirical factors (Table 2) [7].

In this case, in contrast to the codes the influence of the thickness $t$ and radius $R$ of the tank wall is taken into account, besides the principal differences between middle and contour points are indicated. The similar approach was used by other authors (Table 2) $[14,21]$. They in their turn proposed the given ratios on the basis of the structure state analysis and investigations of other researchers as well as requirements of the standards. The results of 
analysing stress condition of the wall tank (Fig 2) of specific capacity with initial parameters $R=11,5 \mathrm{~m}$, $H=12,0 \mathrm{~m}, t=7 \mathrm{~mm}$ are different when the methods considered are used.

It is obvious that the methods are not perfect enough and opinions concerning investigation of the given object are also different. It should be noted that all subjected formulas take into account elastoplastic deformations of the material.

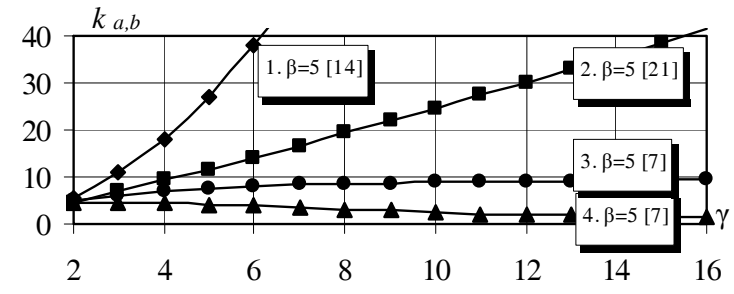

Fig 2. Variation of the stress concentration factor as a function of the dent relative depth, when $\beta=5$

Table 2. The experimental formulas for determining the stress concentration factors on the dent surface

\begin{tabular}{|c|c|c|c|}
\hline 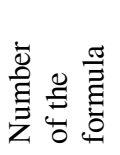 & Stress concentration factor & Value of the proposed formulas factors & 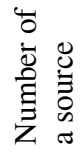 \\
\hline 1 & $k_{a, b}=\frac{\sigma_{\max }}{\sigma_{n}}$ & $\begin{array}{l}\sigma_{\text {max }}=\frac{p(D+t)}{2 t \lambda_{1}}, \sigma_{n}=\frac{p(D+t)}{2 t}, \\
\lambda_{1}=1 \text {, in case } \gamma(f, t)=\frac{f}{t} \leq 0,1 ; \\
\lambda_{1}=\frac{1,105}{\gamma^{2}+\sqrt{\gamma^{2}+1}}, \text { in case } \gamma(f, t)=\frac{f}{t} \geq 0,1\end{array}$ & {$[14]$} \\
\hline 2 & $k_{a, b}=1+B \times \gamma^{m}$ & $\begin{array}{c}B=-0,117 \frac{r^{2}}{R \times t}+0,711 \frac{r}{\sqrt{R \times t}}+1,05 \\
m=0,158 \frac{r}{\sqrt{R \times t}}+0,358\end{array}$ & {$[21]$} \\
\hline 3 & $k_{b}\left(s_{i}, \beta, \gamma\right)=A\left(s_{i}, \gamma\right) \cdot \beta^{m}\left(s_{i}, \beta, \gamma\right)$ & $\begin{array}{r}\mathrm{A}\left(\mathrm{s}_{\mathrm{i}}, \gamma\right)=\mathrm{s}_{1}+\mathrm{s}_{2} \gamma-\mathrm{s}_{3} \gamma^{2}+\mathrm{s}_{4} \gamma^{3}-s_{5} \gamma^{4} \\
\beta^{m}\left(s_{i}, \beta, \gamma\right)=[\beta]^{\left(\mathrm{s}_{6} \ln (\gamma)+\mathrm{s}_{7}\right)} \\
s_{1}=2,57, s_{2}=0,51, s_{3}=0,0688, s_{4}=0,376 \cdot 10^{-2}, \\
s_{5}=0,75 \cdot 10^{-4}, s_{6}=0,169, s_{7}=0,153\end{array}$ & [7] \\
\hline 4 & $k_{a}\left(q_{i}, \beta, \gamma\right)=\frac{P_{1}\left(q_{i}, \beta, \gamma\right)}{P_{2}\left(q_{i}, \beta, \gamma\right)}$ & $\begin{array}{l}P_{1}\left(q_{i}, \beta, \gamma\right)=q_{1}+q_{2} \beta-q_{3} \beta^{2}+q_{4} \beta^{3}+q_{5} \beta \gamma-q_{6} \beta^{2} \gamma- \\
\quad-q_{7} \beta^{3} \gamma+q_{8} \beta \gamma^{2}-q_{9} \gamma^{2} \\
\begin{array}{l}P_{2}\left(q_{i}, \beta, \gamma\right)= \\
q_{10}-q_{11} \beta+q_{12} \beta^{2}-q_{13} \beta \gamma-q_{14} \beta^{2} \gamma+\gamma^{2}\end{array} \\
\begin{aligned} \gamma(f, t)=\frac{f}{t} \\
\beta(r, R, t)=\frac{r}{\sqrt{R t}} 1\end{aligned} \\
\begin{array}{l}q_{1}=56,1 ; q_{2}=27,4 ; q_{3}=0,821 ; q_{4}=0,286 ; q_{5}=0,057 ; \\
q_{6}=0,034 ; \\
q_{7}=0,028 ; q_{8}=0,161 ; q_{9}=0,150 ; q_{10}=59,5 ; q_{11}=9,71 ; \\
q_{12}=1,79 ; q_{13}=0,378 ; q_{14}=0,174\end{array}\end{array}$ & [7] \\
\hline
\end{tabular}

Here $q, s$ - empirical factors; $\beta$ - relative radius of the dent; $\gamma$ - relative depth of the dent; $f$ - depth of the dent;

$t$ - thickness of the shell in the defect place; $r$ - radius of the dent; $R$ - radius of the shell; $p$ - pressure on the shell;

$D$ - diameter of the shell; $\lambda_{I}$ - factor which takes into account the defect influence on the stress distribution in the shell. 


\section{Numerical models}

In order to check whether formulas (Table 2) are correct, modelling of the defect for a real structure has been performed. In this case the main solutions are made by using a standard finite elements program COSMOS/M [26].

For solution of the problem by this software (Fig 1), a portion of the cylindrical tank shell was taken considering conditions of geometrical shape symmetry and loading by the liquid pressure from within. Triangle finite elements (FE) of "SHELL“ type are expressed by 3 nodes and described by 18 degrees of freedom (DOF). Dimensions of the finite elements on the defect place do not exceed $1 \mathrm{~mm}$. In order to simulate the real situation, the ground pressure on the tank bottom was considered via conventional rigidities of $10,0 \mathrm{MPa}$. The created model reflects the natural location of a dent on the entire tank and real conditions of its operation.

A segment of the tank was loaded by self-weight and by the product pressure which has been linearly applied. The selection of the defect shapes was based upon observation of real structures [7, 21, 27, 28].

\section{Finite elements mesh}

In the present research the analysed ,soft" defect in the form of a dent has two dangerous areas. They are middle and contour areas of the dent. Within each marked area there are peculiar points of the stresses or displacements concentration. For the examined defect there are points , $a$ “ and ,,$b^{\text {“. }}$. Across the dent place the distribution of the stresses and displacements during action of the internal pressure on the wall with a defect does not correspond to a classical theory of shells. While investigating concentration of stresses and displacements within the dent area across the cylindrical surface by means of the finite element method in the first place, the question arises about the finite element dimension for sampling within the defect area [29-31]. In order to determine the finite element optimum size the results of the numerical calculations of the tank wall with the dent have been analysed. As a result, one obtained two relationships between value of relative circular stresses $\sigma^{*}$ and finite element sizes $\zeta$ (Fig 3) as well as between relative displacements $\mathrm{u}^{*}$ and finite element sizes $\zeta$ (Fig 4) at the typical points of the dent.

On the vertical axis of the graphs (Figs 3,4) accordingly relative circular stresses $\sigma^{*}$ and relative displacements $u^{*}$ of the typical points of the dent are marked. On the horizontal axis, relative sizes $\zeta$ of the finite element are indicated. Here relative circular stresses $\sigma^{*}$ are relations between the circular stress at the defect place and the stress in the shell without defect. The relative displacement $u^{*}$ is a relation between perpendicular to a middle surface of the wall tank displacement in the defect place and displacement of the shell at the same place without a defect.
The $\zeta$ value is determined by a relation between finite element size and radius of the dent. For determining the optimum size of the finite element a part the real tank wall with a semi spherical dent was analysed [32-34]. The mean sizes of the defect, $\beta>1$, were considered. Because in case of the imperfection when $\beta=1$ extreme values of the stresses and displacements are always in the peculiar points of the dent. In case of the imperfection when $\beta>1$ point with extreme values can dispose between mentioned points. So for a numerical analysis the largest imperfection should be use more exact mesh of the FE. The basic data of the analysed model of the tank wall are: dent radius $r=851 \mathrm{~mm}$ (relative dent radius $\beta=3$ ), depth dent $f=63 \mathrm{~mm}$ (relative depth dent $\gamma=9$ ), thickness of the bottom $t=7 \mathrm{~mm}$, thickness of the wall $t=7 \mathrm{~mm}$, tank radius $R=11,5 \mathrm{~m}$. The size of the finite element was changed from $200 \mathrm{~mm}$ to $2,0 \mathrm{~mm}$, relative size $\zeta$ from 28,6 to 0,3 , accordingly.

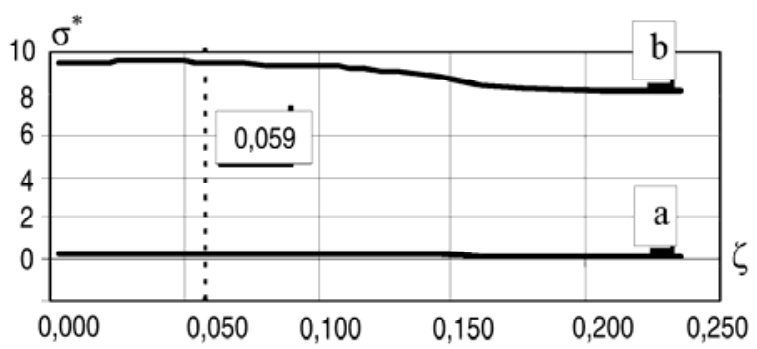

Fig 3. The dependence between value of the relative circular stresses and relative sizes of the finite element at typical points of the defect: a - middle point of the defect; $b$ - upper point of the defect

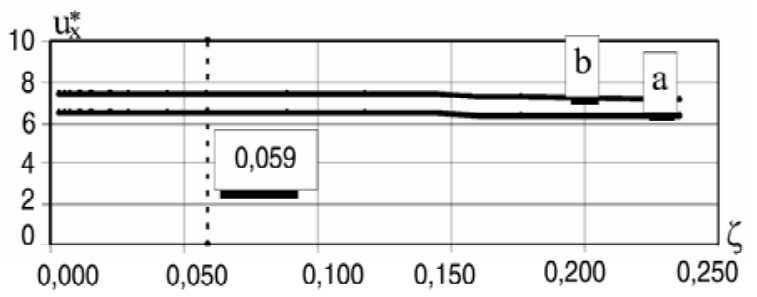

Fig 4. The dependence between value of the relative displacements and relative sizes of the finite element at typical points of the defect: a - middle point of the defect; $b$ - upper point of the defect

The presented results (Fig 3) clearly show that size of the finite element at the defect place is more important for a contour point's results than for its middle part. The optimum size of the finite element is $50 \mathrm{~mm}(\zeta=7,1)$. With such relations between size of the finite element and defect radius the difference between neighbouring results is not more than $1,7 \%$.

In further calculations a finite element which size does not exceed $50 \mathrm{~mm}(\zeta=7,1)$ was used (Fig 5). 

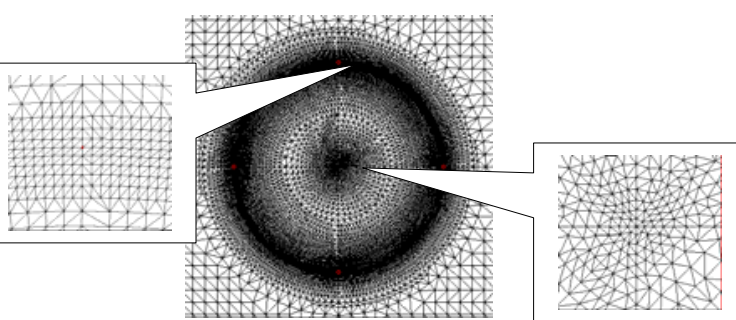

Fig 5. The mesh sampling of the wall tank on the defect place

a

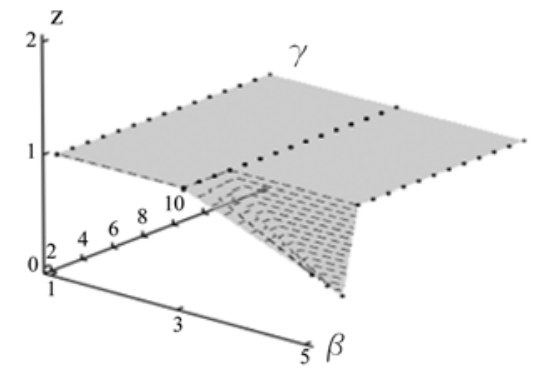

b
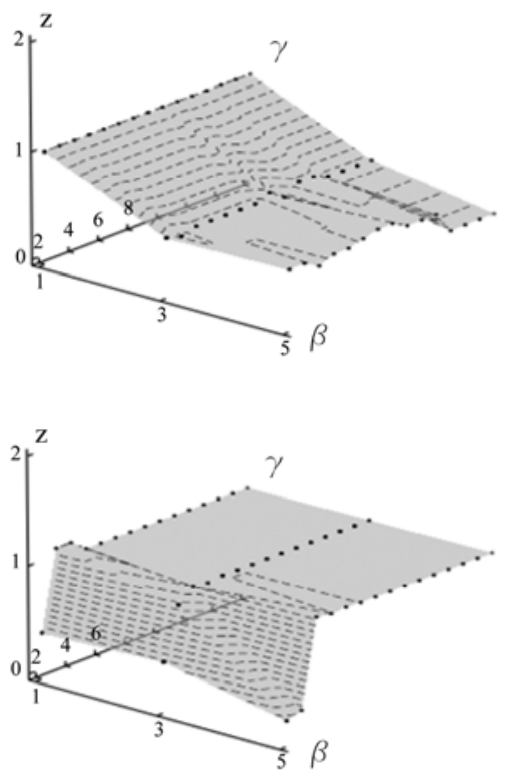

d

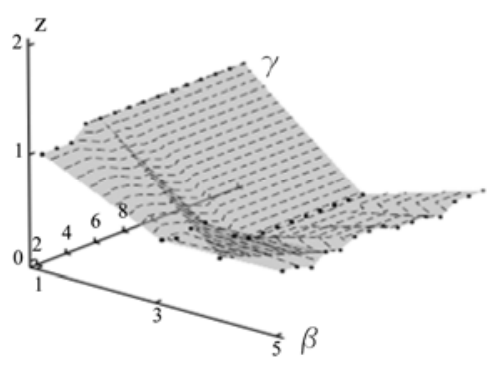

Fig 6. Variation of the location of a point with maximum value of the stress on the dent surface: linear calculation results (a); geometrical non-linear calculation results (b); physical non-linear calculation results (c); geometrical-physical non-linear calculation results $(\mathrm{d})$

\section{Results of calculations by finite elements method}

\subsection{Description of the solutions}

In this research as a calculated numerical model of the tank we use the wall part with the local defect which relative radius $\beta \leq 5 \quad(\beta=1$ or $r=283 \mathrm{~mm}$, $\beta=3$ or $r=851 \mathrm{~mm}$ and $\beta=5$ or $r=1418 \mathrm{~mm}$ ) [35]. The imperfection is not considered as local when relative radius $\beta>5$ [28]. For each dent radius mentioned above fifteen numerical calculations using finite elements method (FEM) were performed by changing the defect depth $2 \leq \gamma \leq 16$ [36]. Besides, four calculations were made for each new value of the defect:

- linear calculation;

- geometrical non-linear calculation;

- physical non-linear calculation;

- geometrical and physical non-linear calculation.

The modified Newton-Raphson force control method for geometrically non-linear calculations was used [26]. For physical non-linearity the diagram of the elasto-plastic material with strengthening in a plastic part was applied [26].

As a result of each calculation at typical defect points $a$ and $b$ values of stresses and displacements have been determined. Cases of disagreement between maximum values and typical points of the defect are possible [35]. Therefore the values of the stresses and displacements were detected at the points with a maximum value. The place of these points is detected by a radius from a centre point of the dent to the point with the maximum value.

\subsection{Location of the dent point with maximum value of the stresses and displacements}

Here we shall consider location of the dent point with maximum value of the stresses and displacements depending on the defect sizes $\beta, \gamma$ and used calculation type (Figs 6, 7). Location of the point with maximum stresses and maximum displacements accordingly is shown in (Figs 6,7). On the vertical axes diagrams of the relative distances $z$ from the defect centre to a point with the extreme value are presented. The relative distance $z$ represents a ratio of an absolute radius $l$ from the defect centre to the point of maximum values and defect radius.

In case of the linear calculation when relative radius and depth of the dent $\beta=12 \leq \gamma \leq 16, \beta=3$ $2 \leq \gamma \leq 16$ and $\beta=5 \quad 5 \leq \gamma \leq 16$ maximum values of the stresses agree with the defect contour (Fig 6 a). But when $\beta=5,2 \leq \gamma<5$ maximum stresses agree with a middle part of the dent (Fig 6 a). In case of the geometrical non-linearity calculation (Fig 6 b) and geometrical - physical non-linearity calculation (Fig 6d) when $\beta=3 \quad 2 \leq \gamma \leq 16, \beta=5 \quad 2 \leq \gamma \leq 16$ (Fig 6 b), $\quad \beta=3 \quad 2 \leq \gamma \leq 16, \quad \beta=5 \quad 2 \leq \gamma \leq 16$ (Fig $6 \mathrm{~d}$ ) maximum stresses are located in the middle 
part of the dent. But when $\beta=1 \quad 3 \leq \gamma \leq 16$ in all cases of the calculations maximum stresses are positioned on the dent contour (Fig $6 \mathrm{~b}, 6 \mathrm{c}, 6 \mathrm{~d}$ ). In case of only physical non-linearity calculations results of the distribution of the maximum stresses (Fig $6 \mathrm{c}$ ) are almost equal to linear calculations results (Fig 6 a). The differences between physical and linear calculations results appear when $\beta=1$ and $\gamma=2$, $\beta=3$ and $\gamma=2$. In other cases of the physical calculations maximum stresses are disposed in the contour part of the defect.

a

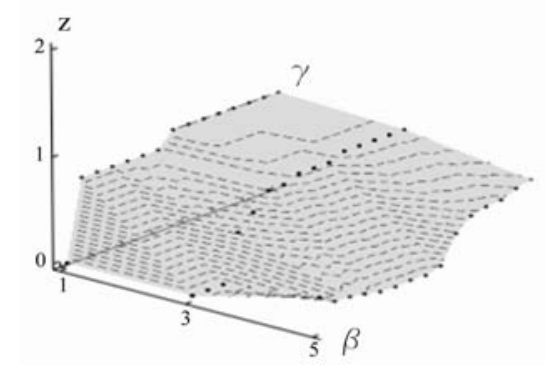

b

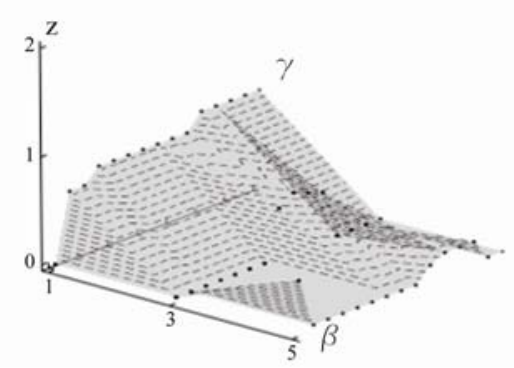

c

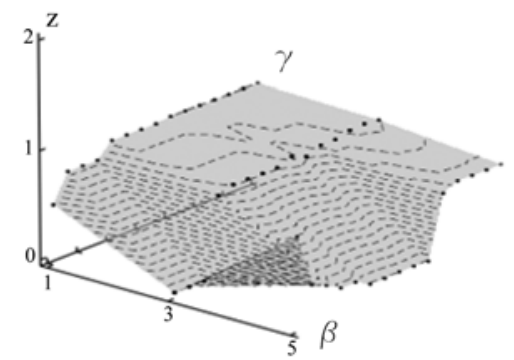

d

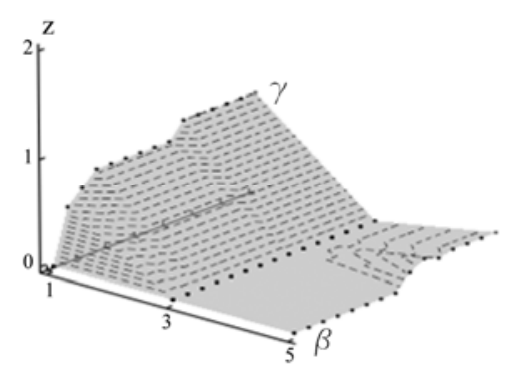

Fig 7. Variation of the location of a point with maximum value of the displacement on the dent surface: linear calculation results (a); geometrical nonlinear calculation results (b); physical non-linear calculation results (c); geometrical-physical non-linear calculation results $(\mathrm{d})$
Analysing further the calculations results we can see that location of the points with maximum stresses (Fig 6) does not agree with that one of the points with maximum displacements (Fig 7) in case of the same defect. Especially it is obvious for case of the linear calculations (Figs 6 a, 7 a). Maximum displacements normal to the tank wall within the defect area with its loading correspond to the dent middle portion when $\beta=3 \quad 2 \leq \gamma \leq 6, \beta=5 \quad 2 \leq \gamma \leq 10$ (Fig 7 a). With decrease in the dent radius and increase in its depth the dent contour portion to a larger degree starts its deformation, when $\beta=1 \quad 3 \leq \gamma \leq 16, \quad \beta=3$ $7 \leq \gamma \leq 16, \beta=512 \leq \gamma \leq 16$ (Fig 7 a). In case of the physical non-linear calculation the location of the point with maximum displacements (Fig $7 \mathrm{c}$ ) agrees with linear calculation results (Fig 7 a). The calculation with geometrical non-linearity changes location of the point with maximum displacement. When $\beta=3 \quad 2 \leq \gamma \leq 16, \beta=5 \quad 2 \leq \gamma \leq 16$ maximum displacements are observed in the middle point , $a^{\text {“ }}$ or in the middle part of the dent (Figs $7 \mathrm{~b}, 7 \mathrm{~d}$ ). With decrease in dent radius $\beta=1$ and with depth dent increase $5 \leq \gamma \leq 16$ maximum displacements take place on the contour or next contour of the defect (Figs 7 b, 7 d).

From the above results it follows that in case of small defect radius $\beta=1$, points having maximum stresses agree with those maximum displacements with all kinds of the calculations. If its radius is increased taking into consideration non-linearity of the structure geometry and material maximum stresses are located between the dent contour and middle areas.

\subsection{Stresses and displacements concentration factors}

In this part of the research distribution of the stress concentration factor (SCF) and displacement concentration factor (DCF) depending on dent sizes, $\beta, \gamma$, and kind of calculation is analysed (Fig 8). In the linear calculations case SCF increases when radius and depth of the dent increase too, $1 \leq \beta \leq 3$ and $2 \leq \gamma \leq 16$ (Fig 8 a). With further increase of defect radius to $\beta=5,2 \leq \gamma \leq 7$ SCF continues to grow (Fig 8 a). Then with increase in depth $8 \leq \gamma \leq 10$ SCF decreases, o when $11 \leq \gamma \leq 16$ SCF increases again (Fig 8 a). The DCF increases at the same time as SCF. But DCF amounts to maximum with decrease in depth, when $\beta=5$ (Fig $8 \mathrm{c}$ ). The linear calculation results are as follows: the maximum stresses are disposed on the contour dent (Fig 6 a) and maximum SCF is $k=7,0$ when $\gamma=16, \beta=3$. Maximum displacements are on the middle part of the dent and maximum DCF is $\chi=63,0$ when $\gamma=6, \beta=5$ (Fig $8 \mathrm{c}$ ). 
The geometrical non-linearity (GNL) of deformation of the tank wall and its material physical nonlinearity (FNL) result is a more uniform distribution of stresses and displacements on the dent surface. It causes the decrease of SCF (Fig $8 \mathrm{~b}$ ) and DCF (Fig 8 d). But with every kind of the calculation, GNL and FNL, separately have a different influence on the distribution value of the SCF with the same dent sizes. The SCF and DCF in both calculation cases increase with an increase of dent radius $1 \leq \beta \leq 3$ and dent depth $2 \leq \gamma \leq 16$. Further, in case of GNL, SCF decreases with an increase of radius to $\beta=5$; in case of FNL, SCF increases with variable decreasing and increasing. The DCF increases constantly with increasing of the defect in both calculation cases.

a

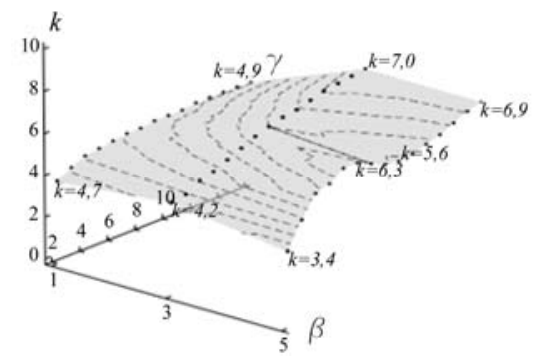

$\mathrm{b}$
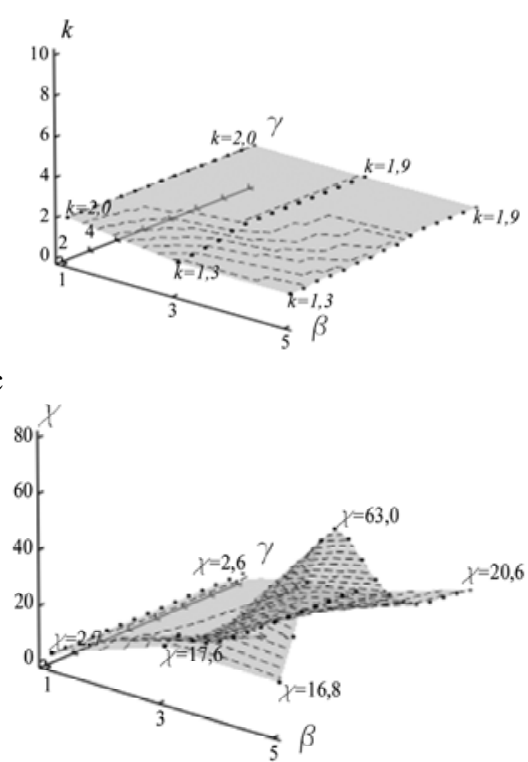

d

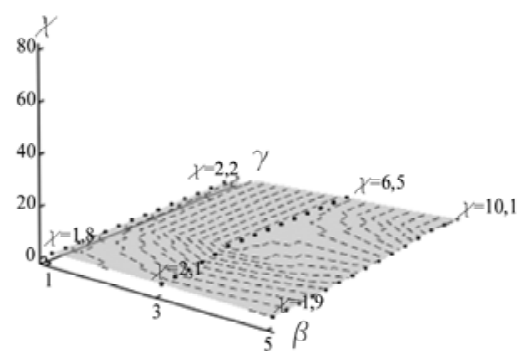

Fig 8. Variation of SCF (a, b) and DCF (c, d) depending on defect sizes and factors $\beta$ and $\gamma$ : linear calculation results $(\mathrm{a}, \mathrm{c})$; geometrical-physical nonlinear calculation results $(b, d)$
In case of geometrical-physical non-linear calculation, values of the SCF and DCF decrease greatly in comparison with linear calculation results (Fig 8 b, d). It is a result of a more uniform distribution of the deformations. From diagrams we can see, that an increase of the dent radius and depth has less influence on SCF resulting in its decrease (Fig $8 \mathrm{~b}$ ). The SCF is $k=2,0$ when $\beta=1 \quad 2 \leq \gamma \leq 16$ and $1,3 \leq k \leq 1,9$ when $\beta=3, \beta=52 \leq \gamma \leq 16$. The difference between SCF values with a constant depth of the dent and with increasing its radius is reduced from $35 \%$ at smaller depths of the defect to $5 \%$, when $12 \leq \gamma \leq 16$.

In case of the geometrical-physical non-linear calculation, we can see a clear dependence between DCF and sizes of the dent (Fig $8 \mathrm{~d}$ ). The DCF increases with an increase of dent sizes, radius and depth. In case of the geometrical-physical non-linear calculation DCF is greatly less than in the linear one. The maximum DCF is $\chi=10,1$ when $\beta=5 \quad \gamma=16$

(Fig $8 \mathrm{~d}$ ). The difference between DCF values at a constant depth of the dent and with increasing its radius is to $15 \%$, when $\gamma=2$, and to $460 \%$, when $3 \leq \gamma \leq 16$.

Therefore SCF and DCF decrease considerably in case of the geometrical-physical non-linear calculation due to a uniform distribution of deformations. The influence of the depth and radius of the dent on the level value of SCF and DCF decreases $[33,36]$.

Maximum SCF and DCF are given in Table 3.

Table 3. Maximum values of SCF and DCF

\begin{tabular}{|c|c|c|c|c|c|c|}
\hline $\begin{array}{c}\text { Item } \\
\text { No }\end{array}$ & 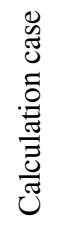 & 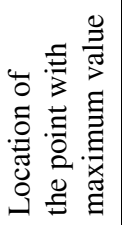 & $\begin{array}{l}\mathrm{SCF}, \\
k_{\max }\end{array}$ & $\begin{array}{l}\text { DCF, } \\
\chi_{\text {max }}\end{array}$ & $\gamma$ & $\beta$ \\
\hline 1 & $\mathrm{~T}$ & 1,000 & 7,0 & & 16 & 3 \\
\hline 2 & $\mathrm{~T}$ & 0,132 & & 63,0 & 6 & 5 \\
\hline 3 & G & 0,549 & 4,9 & & 12 & 3 \\
\hline 4 & G & 0,196 & & 10,0 & 14 & 5 \\
\hline 5 & $\mathrm{~F}$ & 1,000 & 5,1 & & 16 & 5 \\
\hline 6 & GF & 0,876 & 2,0 & & 2 & 1 \\
\hline 7 & GF & 0,196 & & 10,1 & 14 & 5 \\
\hline
\end{tabular}

Table 3 markings: $\mathrm{T}$ - linear calculations results; $\mathrm{G}$ - geometrical non-linear calculations results; $\mathrm{F}$ - physical nonlinear calculation results; GF - geometrical and physical non-linear calculation results. 


\subsection{The comparison results of the calculations by finite elements method with allowable defect sizes according to the present codes}

From comparison of the calculation results and limitations specified by the codes (Table 1) it can be suggested that the given type of defects has not been sufficiently investigated. For comparison of the allowance codes with calculation results obtained according to Eurocode 3 [12] requirements we take a tank classified as that one of good quality class „C“" (Table 1). In this case considering parameters of the tank to be investigated, when the dent relative radius will be equal to $\beta=1$, the allowable dent depth $\gamma=1,3$, then with increase in the dent radius its allowable depth increases: $\beta=3 \gamma=3,9, \quad \beta=5$ $\gamma=6,5$ (Fig 9, 10). It should be noted that with $\beta=1$ the dent is not allowable with all depths to be studied and it requires correction. Then, according to the results presented and taking into account only the linear calculation results (curve „1“ Fig 9, 10), it becomes obvious that sufficiently large SCF values (Fig 9) when $\beta=3$ and $k=4,7, \beta=5$ and $k=6,3$ and almost maximum DCF values (Fig 10) when $\beta=3$ and $\chi=15,4, \quad \beta=5$ and $\chi=61,0$ are allowable.

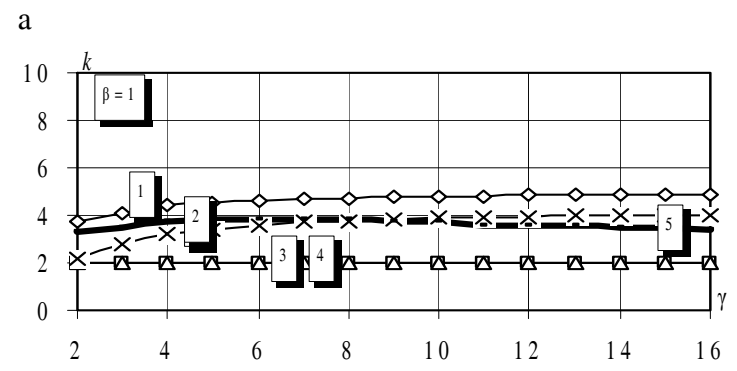

b
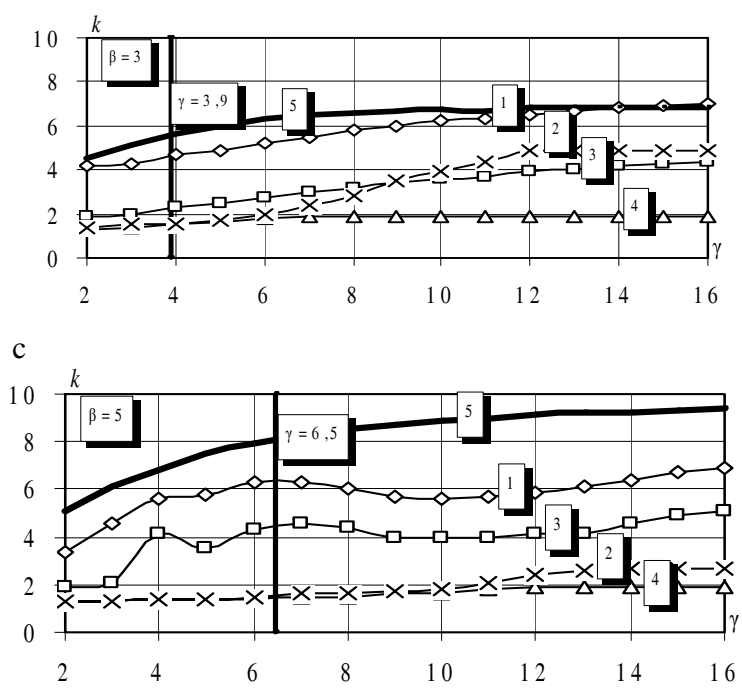

Fig 9. Variation of SCF depending on dent radius, depth and kind of the calculation: $\beta=1$ (a); $\beta=3$ (b); $\beta=5$ (c)
According to the comparison results it follows that the dent sizes have to be more actively allowable. But taking into account geometrical and physical nonlinearity in calculations, a curve number ,4“, SCF and DCF are much less, when $\beta=3$ and $k=1,5, \chi=2,7$, $\beta=5$ and $k=1,4, \chi=4,1$ (Figs 9, 10). Besides SCF decreases with an increase in radius of the dent when the dent depth is constant, DCF increases slightly, this is not being a cause for the tank repair. For example, in case of non-linear calculations, curve number ,4“ (Figs 9, 10) and with a constant depth dent, $\gamma=8,0$, SCF decreases with increasing of the radius dent, when $\beta=1, k=2,0, \beta=3, k=1,9, \beta=5, k=1,5$, DCF increases, when $\beta=1, \chi=2,0, \beta=3, \chi=6,5$, $\beta=5, \chi=5,0$. Moreover, the dent depth in nonlinear calculations has a small influence on SCF and DCF values, curves number „4“ (Figs 9, 10). Also, one should keep in mind that when using tanks in practice defects occur considerably exceeding the allowable ones but these tanks still can be successfully operated. On the diagrams (Figs 9, 10), curves ,2" and ,3“ are considered as realisation of the geometrical and physical non-linear calculations depending on defect sizes.
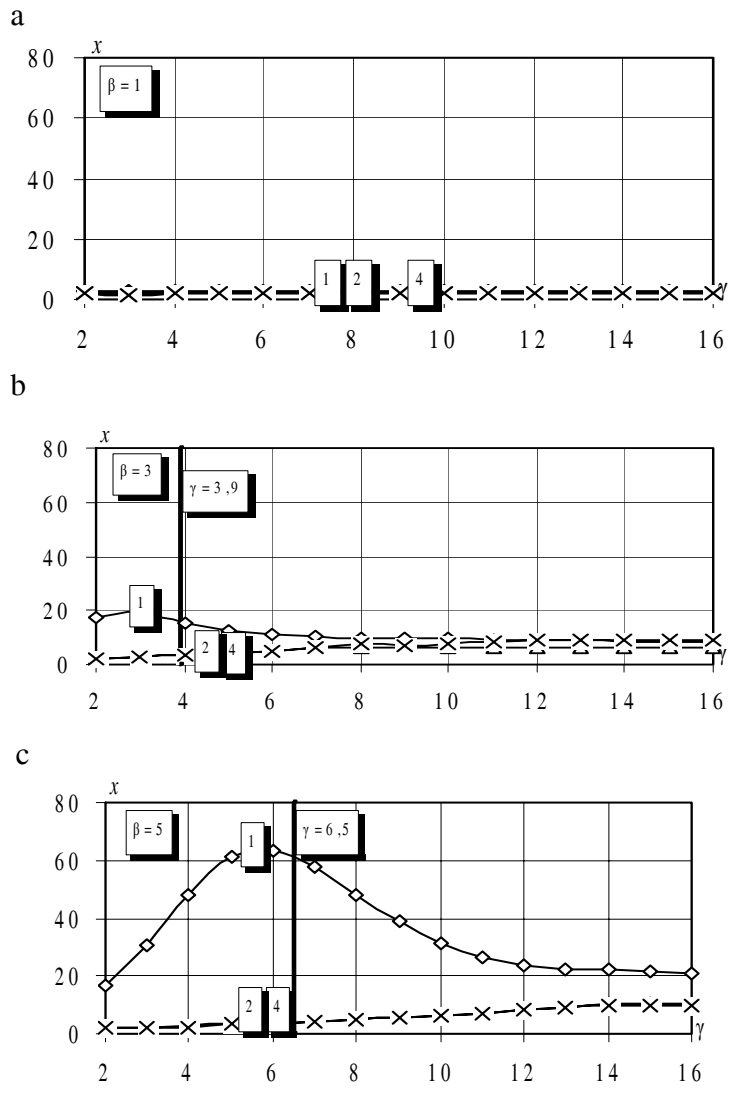

Fig 10. Variation of DCF depending on dent radius, depth and kind of the calculation: $\beta=1$ (a);

$\beta=3$ (b); $\beta=5$ (c) 
From the analytical solutions proposed in the first chapter it follows that the third equation is more appropriate for SCF calculations. It is a curve number ,5“ on the diagrams (Fig 9). According to this equation, variation of SCF depending on the dent sizes agrees generally with FEM calculations results (Fig 9). Analysing further in details each case of the defect $\beta=1,3,5$, we can see that in the first case of the defect $(\beta=1)$ SCF is less, as seen from the proposed formula, than FEM results (Fig 9 a). When the dent radius $\beta=5$, the proposed formula gives a great safety factor in comparison with FEM results (Fig 9 c). But SCF by proposed formula is bigger than in case of calculations FEM, when $\beta=3$ and $2 \leq \gamma \leq 13, \gamma \geq 15$. The SCF is equal in case of both methods, when $\beta=3$ and $\gamma=14$ (Fig $9 \mathrm{~b}$ ). The proposed equation cannot be used in case of the nonlinear calculation because of a great safety factor.

Therefore it follows from this chapter that allowances of the ,soft" defects should be made more exact. The allowances of the defect sizes specified by codes can be increased.

\section{Conclusions}

On the basis of the proposed investigation the conclusions are made:

1. When analysing the stresses and displacements across the defect area, the relative appropriate size of the finite element is $\zeta=7,1$.

2. When the dent radius $\beta=1$, location of the points with maximum stresses agrees with that one of the points with maximum displacement in all cases of calculations. In case of the bigger dent radius, $\beta=3$, $\beta=5$, and in non-linear calculations, maximum stresses are disposed between the dent contour and middle points, maximum displacements are disposed in the middle part of the defect.

3. The SCF and DCF decrease greatly in case of the geometrical-physical non-linear calculation due to the uniform distribution of deformations. The influence of the depth and radius of the dent on the level value of SCF and DCF decreases.

4. The maximum stresses of the linear calculations are disposed on the contour dent, and maximum SCF is $k=7,0$ when $\gamma=16, \beta=3$. Maximum displacements of the linear calculations are on the middle part of the dent, and maximum DCF is $\chi=63,0$ when $\gamma=6, \beta=5$.

5. The maximum stresses of the non-linear calculations are disposed on the contour dent, and maximum SCF is $k=2,0$ when $\gamma=2, \quad \beta=1$. Maximum displacements of the non-linear calculations are on the middle part of the dent, and maximum DCF is $\chi=10,1$ when $\gamma=14, \beta=5$.

6. From the analytical solutions proposed in the first chapter it follows that the third equation is more appropriate for SCF calculations. According to this equation, variation of SCF depending on the dent sizes agrees, generally, with FEM calculations results.

7. The allowances of the ,soft" defects should be made more exactly. The results of carried out investigations witness that allowances of the defect sizes specified by codes can be increased. For a more precise determination of acceptable allowances additional numerical and experimental investigations should be performed.

\section{References}

1. Gorochov, Y.; Muschanov, V.; Kulik, A. and Tsyplukhin, A. Vertical cylindrical tank with angular geometrical imperfection. Journal of Civil Engineering and Management, Vol 11, No 3. Vilnius: Technika, 2005, p. 175-183.

2. Kandakov, G. P.; Kuznecov, V. V. and Lukijenko, M. I. Analysing the crash causes of the vertical cylindrical tanks. Pipeline Transportation (Трубопроводный транспорт), No 5, 1994, p. 15-16 (in Russian).

3. Hornung, U. and Saal, H. Buckling loads of tank shells with imperfections. International Journal of Non-linear Mechanics, No 37, 2002, p. 605-621.

4. Zanulin, R. H. Safe operation of the cylindrical vessels with such defects as „dents“ (Безопасная эксплуатация цилиндрических сосудов с дефектами типа „вмятина“). Kazan: Kazan Technological University, 2000. 17 p. (in Russian).

5. Shvyrkov, S. A.; Semikov, V. L. and Shvyrkov, A. N. Analysis of the statistic data of the tank destructions. Theoretical and Engineering Developments (Научнотеоретические и инженерно-технические разработки), No 5, 1996, p. 39-50 (in Russian).

6. Aliphanov, L. A.; Romanenko, K. and Samofalov, M. FEM application in geometrically non-linear analysis of local shape defects on steel cylindrical tank walls. In: International conf „17th Nordic Seminar on Computational Mechanics“. Stockholm, Oct 15-16, 2004. Proc of conference. 2004, p. 90-93.

7. Aliphanov, L. A. Regulation of the shape defects and resources of the vertical cylindrical tanks (Нормирование дефектов формы и ресурса вертикальных цилиндрических резервуаров). Krasnoyarsk Architectural-Building Academy, PhD thesis, 2004. 165 p. (in Russian).

8. Pircher, M.; Berry, P. A.; Ding, X. and Bridge, R. Q. The shape of circumferential weld-induced imperfections in thin-walled steel silos and tanks. Thin-walled Structure, No 39, 2001, p. 999-1014.

9. Ivanov, S. N.; Golubeva, N. V.; Rodionov, N. V. and Plaksin, J. V. The influence of technological imperfections on safe operation of the tanks. Industrial and Civil Engineering (Промышленное и гражданское строительство), No 5, 1998, p. 27-28 (in Russian).

10. Pircher, M. and Bridge, R. The influence of circumferential weld-induced imperfections on the buckling of silos and tanks. Journal of Constructional Steel Research, No 57, 2001, p. 569-580.

11. LST L ENV 1993-1-6 Design of steel structures. Part 1-6: General rules. Supplementary rules for the shell structures (Plieninių konstrukcijų projektavimas. 
1-6 dalis. Bendrosios taisyklès. Kevalinių konstruokcijų papildomos taisyklès). Vilnius: LSD, 2002. 82 p. (in Lithuanian).

12. European Standard, ENV 1993-1-6 (Eurocode 3): Design of steel structures. Part 1-6: General rules. Supplementary rules for the shell structures, Final draft 1999. $82 \mathrm{p}$.

13. American National Standard, ANSI/API Std. 650: Welded Steel Tanks for Oil Storage, Final draft, 1993. $182 \mathrm{p}$.

14. Russian Inspection Code, RD-08-95-95: Regulation of system technical diagnosis of the welded vertical cylindrical tanks for oil and oil products (Положение о системе технического диагностирования сварных вертикальных цилиндрических резервуаров для нефти и нефтепродуктов), Final draft, 1995. 35 p. (in Russian).

15. German Design Code, DIN 18800: Steel structures. Buckling failure of the shell. (Stahlbauten. Stabilitätsfalle, Schalenbeulen), Vol 4, 1990. 248 p. (in German).

16. European Recommendations For Structural Stability. ECCS-Technical Committee 8, Technical Working Group 8.4: Buckling of steel shells, stability of shells, 4th Edition, 1988. 82 p.

17. Russian Fabrication Code, SNiP III-18-75: The rules of the fabrication and acceptance of the works (Правила производства и приемки работ). Moscow: Stroyizdat, 1976. 167 p. (in Russian).

18. Bielewicz, E. and Gorski, J. Reliability of imperfect structure (simple non-linear models). Journal of Civil Engineering and Management, Vol VIII, No 2. Vilnius: Technika, 2002, p. 83-87.

19. Lichman, V. V.; Kopeysickaya, L. N. and Muratov, V.M. Strength of the welded tanks with shape irregularities in low-cycle loading time. Problems of Strength (Проблемы прочности), No 11-12, 1995, p. 130-136 (in Russian).

20. Winterstetter, Th. A. and Schmidt, H. Stability of circular cylindrical steel shells under combined loading. Thin-walled Structure, No 40, 2002, p. 893-909.

21. Lichman, V. V.; Kopeysickaya, L. N. and Muratov, V. M. Stresses concentration factor in the tanks with local shape defects. Chemical and Oil Engineering (Химическое и нефтегазовое машиностроение), No 6, 1992, p. 22-24 (in Russian).

22. Muhin, V. N. and Elmanovich, V. H. Calculation and experimental evaluation of the local dent influence on strength of the walls of the vessels and devices. Chemical and Oil Engineering (Химическое и нефтяное машиностроение), № 6, 1991, р. 24-26 (in Russian).

23. Cosham, A. and Hopkins, P. The effect of dents in pipelines-guidance in the pipeline defect assessment manual. International Journal of Pressure Vessels and Piping, Vol 81, 2004, p. 127-139.

24. Bordubanov, V. G. Evaluation of load-carrying ability of the pressure cylindrical vessels with surface imperfections at single static load (Оценка несущей способности цилиндрических сосудов давления с поверхностными дефектами при однократном статическом нагружении). Kaunas: Kaunas Technological University, 1986. 20 p. (in Russian).

25. Daniel, C. B. A numerical study on the lateral indentation of continuously supported tubes. Journal of Constructional Steel Research, No 60, 2004, p. 1177-1192.

26. COSMOSM. User`s Guide. 2002. 1289 p.

27. Romanenko, K.; Samofalov, M.; Šapalas, A. and Aliphanov, L.A. Linear and physical non-linear stress state analysis of local shape defects on steel cylindrical tank walls by the finite element method. Mechanika, Vol 46, No 2. Kaunas: Technologija, 2004, p. 5-13.

28. Aliphanov, L. A.; Romanenko, K.; Moskvichev, V. V.; Lepikhin, A. M. and Samofalov, M. Analysis of geometrical shape defects of a steel cylindrical tank wall by numerical and analytical methods. In: Proc of the 8th International Conference „Modern Building Materials, Structures and Techniques". Selected papers. Ed by E. K. Zavadskas, P. Vainiūnas and F. M. Mazzolani. Vilnius: Technika, 2004, p. 334-342.

29. Kačianauskas, R. The semianalitic finite elements and their application for modelling of the cilindrical shells. Statyba (Civil engineering), No 1(9). Vilnius: Technika, 1997, p. 39-48 (in Lithuanian).

30. Aliphanov, L. A. and Moskvichev, V. V. The Mode of Deformation of Storage Tanks with Shape Defects. Computation Technology (Вычислительные технологии), Vol 7, 2002, p. 16-22.

31. Romanenko, K. and Samofalov, M. Numerical Modelling of Mechanical Behavior Near the Holes of a Cylindrical Steel Tank. In: Proceedings of the international conference „Mechanika-2003“. Kaunas: Technologija, 2003, p. 339-344 (in Lithuanian).

32. Aliphanov, L. A.; Lepikhin, A. M.; Moskvichev, V. V. and Romanenko K. Substantiation of tolerances of the dents depth on the steel cylindrical tanks walls. In: VII All-Russian scientific conference. Modern methods of the mathematic modelling of natural and anthropogenic catastrophes (VII Всероссийская научная конференция «Современные методы математического моделирования природных и антропогенных катастроф). Krasnoyarsk, Oct 13-17, 2003. Proc of conference. 2003, p. 11-19 (in Russian).

33. Romanenko, K.; Šapalas, A.; Kvedaras, A. K. and Samofalov, M. Physical and geometrical non-linearity in stress/strain state FE analysis of thin walled structures. In: International conference „17th Nordic Seminar on Computational Mechanics“. Stockholm, Oct 15-16, 2004. Proc of the conference. 2004, p. $179-182$.

34. Greiner, R. and Derler, P. Effect of Imperfections on Wind-Loaded Cylindrical Shells. Thin-walled Structure, No 23, 1995, p. 271-281.

35. Romanenko, K. and Samofalov M. Analysis and estimation of the soft defects on the thin wall tankages. In: Proc of the $10^{\text {th }}$ International Conference Mechanics. Kaunas: Technologija, 2005, p. 17-23 (in Lithuanian).

36. Romanenko, K.; Samofalov, M.; Šapalas, A. and Aliphanov L. A. Linear and physically non-linear analysis by the finite element method of mechanical state of local shape defects on steel cylindrical tank walls. In: Proc of the International Conference „Mechanics-2004“. Kaunas: Technologija, 2004, p. 56-61 (in Lithuanian). 


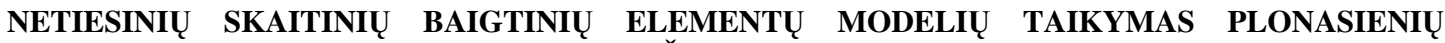 PLIENINIŲ CILINDRINIŲ TALPYKLŲ MINKŠTIESIEMS DEFEKTAMS İVERTINTI}

\section{K. Rasiulis, M. Samofalov, A. Šapalas}

Santrauka

Plieninès talpyklos ir tokio tipo inžineriniai statiniai projektuojami, atsižvelgiant i ilgalaikę ju eksploatacija. Didelių statinių remontas ir profilaktinè priežiūra yra gana brangūs procesai, todèl svarbus talpyklų defektŭ skaitinis tyrimas. Talpyklų minkštujų defektų natūriniai stebėjimai (stebėtos talpyklos nuo 1000 iki $50000 \mathrm{~m}^{3}$, sąlyginis defektų skersmuo nuo 0,40 iki 4,50 m, gylis iki $120 \mathrm{~mm}$ ) parodè, kad normavimo metodikos yra netikslios. Šiame darbe siekiama parinkti tinkamą baigtinio elemento dydį plonasienių plieninių cilindrinių talpyklų geometriniams defektams modeliuoti taikant baigtinių elementų metoda, nustatyti ịtempių ir deformacijų būvị defekto vietoje, palyginti siūlomus analitinius sprendimus bei standartų reikalavimus su baigtinių elementų metodo rezultatais. Siūlomos išraiškos tikrinamos gretinant realių objektų skaičiavimo ir natūriniu stebejjimų rezultatus. Geometrinių defektų mechaninis būvis papildomai modeliuojamas baigtinių elementų metodu.

Reikšminiai žodžiai: plieninè cilindrinè talpykla, defektas, skaitinis modelis, baigtinis elementas, geometrinis netiesiškumas, fizinis netiesiškumas, įtempių ir deformacijų būvis.

Konstantin RASIULIS. PhD student of Dept of Steel and Timber Structures. Vilnius Gediminas Technical University, Saulètekio Ave 11, LT-10223 Vilnius, Ph.: 2745228, 2308716, 869837753, fax: 2481863, Lithuania. E-mail: rasiulis@st.vtu.lt

A graduate of Civil and Industry Engineering of Krasnoyarsk Academy of Architecture and Civil Engineering (1998). MSc of Civil Engineering (2003) at Vilnius Gediminas Technical University. Research interests: finite element method, design and numerical modelling of tank defects, engineering software for civil engineering, inspection of real industrial processes.

Michail SAMOFALOV. PhD Assoc Prof of Dept of Strength of Materials. Vilnius Gediminas Technical University, Saulètekio Ave 11, LT-10223 Vilnius, Lithuania. E-mail: ms @fm.vtu.lt.

A graduate of Civil Engineering Faculty of Vilnius Technical University (1995), MSc in informatics (1997) and $\mathrm{PhD}$ in mechanics (2002). Research interests: computational mechanics, finite element method, inspection and numerical modelling of thin-walled structures, technical software.

Antanas ŠAPALAS. PhD Prof of Dept of Steel and Timber Structures. Vilnius Gediminas Technical University, Saulètekio Ave 11, LT-10223 Vilnius, Lithuania. E-mail: Antanas.Shapalas@st.vtu.lt.

A graduate of Civil Engineering Faculty of Vilnius Civil Engineering Institute (1982), $\mathrm{PhD}$ in civil engineering (1989). Research interests: design of steel and timber structures, geometric non-linearity of steel masts with guys, inspection and real processes in civil and industrial engineering. 